九州大学学術情報リポジトリ

Kyushu University Institutional Repository

\title{
Morphological and Physiological Variation in Lablab Bean (Lablab purpureus (L...) Sweet)
}

Sultana, Nasreen

Laboratory of Horticultural Science, Division of Agricultural Botany, Department of Plant Resources, Graduate School of Bioresource and Bioenvironmental Sciences, Kyushu University

Ozaki, Yukio

Laboratory of Horticultural Science, Division of Agricultural Botany, Department of Plant Resources, Faculty of Agriculture, Kyushu University

Okubo, Hiroshi

Laboratory of Horticultural Science, Division of Agricultural Botany, Department of Plant Resources, Faculty of Agriculture, Kyushu University

https://doi.org/10.5109/24396

出版情報: 九州大学大学院農学研究院紀要. 45 (2)，pp.465-472，2001-02-28. Kyushu University バージョン：

権利関係 : 


\title{
Morphological and Physiological Variation in Lablab Bean (Lablab purpureus (L.) Sweet)
}

\author{
Nasreen Sultana', Yukio Ozaki and Hiroshi Okubo \\ Laboratory of Horticultural Science, Division of Agricultural Botany, Department of \\ Plant Resources, Faculty of Agriculture, Kyushu University, \\ Fukuoka 812-8581, Japan \\ (Received October 31, 2000 and accepted November 10, 2000)
}

\begin{abstract}
A total of 107 lablab bean germplasm representing 20 different countries were evaluated for major morphological characters such as growth habit, plant type, number of branches, flowering response to photoperiod, pigmentation on stem, petiole, leaf vein, leaf margin, petal, sepal, pod and seed coat and size of leaf, pod and seed. Variation was found among the germplasm (dissimilarity value ranged from 0.0-114.6) but no definite regional gene pool was identified. Wild type accessions were very close in their morphology, whereas Asian accessions showed much variation.
\end{abstract}

\section{INTRODUCTION}

Lablab or hyacinth bean (Lablab purpureus) is one of the important legume vegetables cultivated in India and Bangladesh since earliest time and a great number of land races are found in this area (Purseglove, 1977; Rashid, 1993). India, Southeast Asia or Africa is thought to be the origin of lablab bean, although presently it is cultivated all over the world. In southeast India it is one of the major source of dietary protein (Shivashankar et al., 1993). In Northern Australia it is extensively used as lay legume, providing high yield of forage and it improves the yield and protein content of subsequent grain crops (Lloyd et al., 1991).

With its potential to be a major legume vegetable, it is still a less advanced crop. Sporadic developmental works have been done in India, Bangladesh and very recently in Australia (Shivashankar et al., 1993; Rashid, 1993; Konduri et al., 2000).

As a part of variety development program, present study was conducted to clarify the amount of variability available for different component characters in this crop. Therefore, the main objectives were to collect information on genetic divergence among the existing varieties and to elucidate the relationship of genetic diversity with their geographical and ecological background.

\section{MATERIALS AND METHODS}

\section{Plant materials}

A total of 107 lablab bean accessions was used. Thirteen accessions were collected

\footnotetext{
${ }^{1}$ Laboratory of Horticultural Science, Division of Agricultural Botany, Department of Plant Resources, Graduate School of Bioresource and Bioenvironmental Sciences, Kyushu University

${ }^{1}$ Corresponding author
} 
from Bangabandhu Sheikh Mujibur Rahman Agricultural University, Bangladesh (formerly Institute of Postgraduate Studies in Agriculture, IPSA). Among them, 11 accessions, IPSA-1 to IPSA-11 were developed at IPSA and released by National Seed Board. They are photoinsensitive and year round variety. 'Noldog' was also a variety of IPSA selected from local land races. JER was a variety of Japan and was used as one of the parent in the hybridization program at IPSA. Twenty accessions were collected from Plant Genetic Resource Center (PGRC) of Bangladesh Agricultural Research Institute (BARI). They had been collected from different parts of the country. Eleven accessions were introduced from Asian Vegetables Research and Development Center (AVRDC), Taiwan, among which two were from Indonesia, five from Philippines and four from Thailand. Sixty accessions were provided by Commonwealth Scientific and Industrial Research Organization (CSIRO), Australia. They were from Angola (4 accessions), Brazil (3), China (1), Colombia (1), Hungary (1), India (24), Indonesia (3), Kenya (2), Myanmar (2), Russia (2), South Africa (1), Sudan (1), Tanzania (1), USSR (1), Zambia (4) and Zimbabwe (3). Besides, two cultivars, Rongai from Kenya and Highworth from India and other two unknown varieties were also from CSIRO. Two Japanese commercial varieties and one determinate accession from India were also used.

Seeds of all accessions from Bangladesh, AVRDC and Japan were sown in plastic pots (12 cm in diameter) containing a mixture of pumice: vermiculite: sand $(1: 1: 1, \mathrm{v} / \mathrm{v} / \mathrm{v})$ on 10 April 1998 and grown in a plastic house of Kyushu University. Those from CSIRO were sown and grown in the same manner as above on 3 March 1999. Morphological and physiological characteristics as listed in Table 1 were recorded.

\section{Cluster analysis}

A data matrix was generated from the parameters of characteristics as listed in Table 1 except petal, sepal and pod color and pod length due to the lack of flowering of some accessions. Morphological dissimilarity among the accessions was calculated using the Unweighted Pair-Group Method using Arithmetic average (UPGMA).

\section{RESULTS AND DISCUSSION}

\section{Growth habit, plant type, number of branches and photoperiod sensitivity}

Two types of growth habit, determinate and indeterminate were observed among the collections (Table 2). The only determinate accession was found in India, one of the most believed places of origin of this crop, whereas no determinate growth habit was found in Africa, which is thought to be another probable place of origin. Indeterminate character appeared to be the most abundant growth habit of lablab bean in nature. In a descriptive report of 92 lablab bean accessions no determinate growth habit was found by Piper and Morse (1915). In an Indian collection of 255 accessions of lablab bean, $11.37 \%$ determinate accession was reported by Shivashankar et al. (1977).

Plant type of determinate accession was classified as dwarf bush. Among other accessions, 39\% were SS, 16\% were MS and 45\% were LS types. About 35\% accessions had few branching, 29\% had moderate and 36\% had many branching. Most of the SS type plants had few branching, whereas moderate to many branching types were in medium to large spreading type plants. 
Table 1. Parameters of morphological and physiological characters studied in the collected lablab bean accessions.

\begin{tabular}{|c|c|c|c|}
\hline Item & Parameter & Item & Parameter \\
\hline $\begin{array}{l}\text { A Growth } \\
\text { habit }\end{array}$ & $\begin{array}{l}\text { 1: Indeterminate } \\
\text { 9: Determinate }\end{array}$ & $\begin{array}{l}\text { K Pod } \\
\text { color }\end{array}$ & $\begin{array}{l}\text { 1: White } \\
\text { 4: Green }\end{array}$ \\
\hline $\begin{array}{l}\text { B Plant } \\
\text { type }\end{array}$ & $\begin{array}{l}\text { 1: Dwarf bush } \\
\text { 4: Small spreading vine (SS) } \\
\text { ( } 0.7 \text { to } 1.4 \mathrm{~m} \text { high and } 0.5 \text { to } 0.6 \mathrm{~m} \text { wide) }\end{array}$ & & $\begin{array}{l}\text { 6: Mixed (Purple with white or green) } \\
\text { 9: Purple }\end{array}$ \\
\hline & $\begin{array}{l}\text { 6: Medium spreading vine (MS) } \\
\text { (1.0 to } 1.5 \mathrm{~m} \text { high and } 0.7 \text { to } 1.0 \mathrm{~m} \text { wide) } \\
\text { 9: Large spreading vine (LS) } \\
\text { (More than } 1.5 \mathrm{~m} \text { high and } 1.0 \mathrm{~m} \text { wide) }\end{array}$ & $\begin{array}{l}\text { L Seed } \\
\text { coat } \\
\text { color }\end{array}$ & $\begin{array}{l}\text { 1: Yellowish white } \\
\text { 2: Yellowish brown } \\
\text { 3: Mixed (Yelloish white with } \\
\text { brown) }\end{array}$ \\
\hline $\begin{array}{l}\text { C No. of } \\
\text { branches }\end{array}$ & $\begin{array}{l}\text { 1: A few ( } 1 \text { to } 3 \text { branches) } \\
\text { 5: Moderate ( } 4 \text { to } 6 \text { branches) } \\
\text { 9: Many (More than } 6 \text { branches) }\end{array}$ & & $\begin{array}{l}\text { 5: Brown } \\
\text { 7: Chocolate } \\
\text { 9: Black }\end{array}$ \\
\hline $\begin{array}{l}\text { D Response } \\
\text { to photo } \\
\text { period }\end{array}$ & $\begin{array}{l}\text { 1: Insensitive (Bloom all year round) } \\
\text { 4: Less sensitive (Bloom twice a year) } \\
\text { 6: Sensitive (Bloom only in very short day) } \\
\text { 9: Highly sensitive (No bloom at all) }\end{array}$ & $\begin{array}{l}\text { M Pod } \\
\text { length }\end{array}$ & $\begin{array}{l}\text { 1: Long (Longer than } 8 \mathrm{~cm}) \\
\text { 5: Medium }(4 \text { to } 8 \mathrm{~cm}) \\
\text { 9: Short (Shorter than } 4 \mathrm{~cm})\end{array}$ \\
\hline $\begin{array}{l}\text { E Stem } \\
\text { color }\end{array}$ & $\begin{array}{l}\text { 1: Light green } \\
\text { 3: Green } \\
\text { 5: Mixed (Light green and purple) } \\
\text { 6: Mixed (Green and purple) } \\
\text { 7: Red purple } \\
\text { 9: Purple }\end{array}$ & $\begin{array}{l}\text { O Seed } \\
\text { size }\end{array}$ & $\begin{array}{l}\text { 1: Big (Bigger than } 7 \times 4.5 \mathrm{~cm} \text { ) } \\
\text { 5: Medium ( } 5 \times 3.5 \text { to } 7 \times 4.5 \mathrm{~cm} \text { ) } \\
\text { 9: Small ( Smaller than } 5 \times 3.5 \mathrm{~cm} \text { ) } \\
\text { 1: Large (Larger than } 41 \mathrm{~g} / \\
\text { 100 seed wt) }\end{array}$ \\
\hline $\begin{array}{l}\text { F Petiole } \\
\text { color }\end{array}$ & $\begin{array}{l}\text { 1: Green } \\
\text { 5: Mixed } \\
\text { 9: Purple }\end{array}$ & & $\begin{array}{l}\text { 5: Medium(15 to } 40 \mathrm{~g} / \\
100 \text { seed wt.) } \\
\text { 9: Small (Less than } 15 \mathrm{~g} /\end{array}$ \\
\hline $\begin{array}{l}\text { G Leaf } \\
\text { margin } \\
\text { color }\end{array}$ & $\begin{array}{l}\text { 1: Green } \\
\text { 9: Purple }\end{array}$ & & 100 seed wt.) \\
\hline $\begin{array}{l}\text { H Leaf } \\
\text { vein } \\
\text { color }\end{array}$ & $\begin{array}{l}\text { 1: Green } \\
\text { 9: Purple }\end{array}$ & & \\
\hline $\begin{array}{l}\text { I Petal } \\
\text { color }\end{array}$ & $\begin{array}{l}\text { 1: White } \\
\text { 5: Light purple } \\
\text { 9: Purple }\end{array}$ & & \\
\hline $\begin{array}{l}\text { J Sepal } \\
\text { color }\end{array}$ & $\begin{array}{l}\text { 1: White } \\
\text { 4: Green } \\
\text { 6: Mixed (Purple with white or green) } \\
\text { 9: Purple }\end{array}$ & & \\
\hline
\end{tabular}




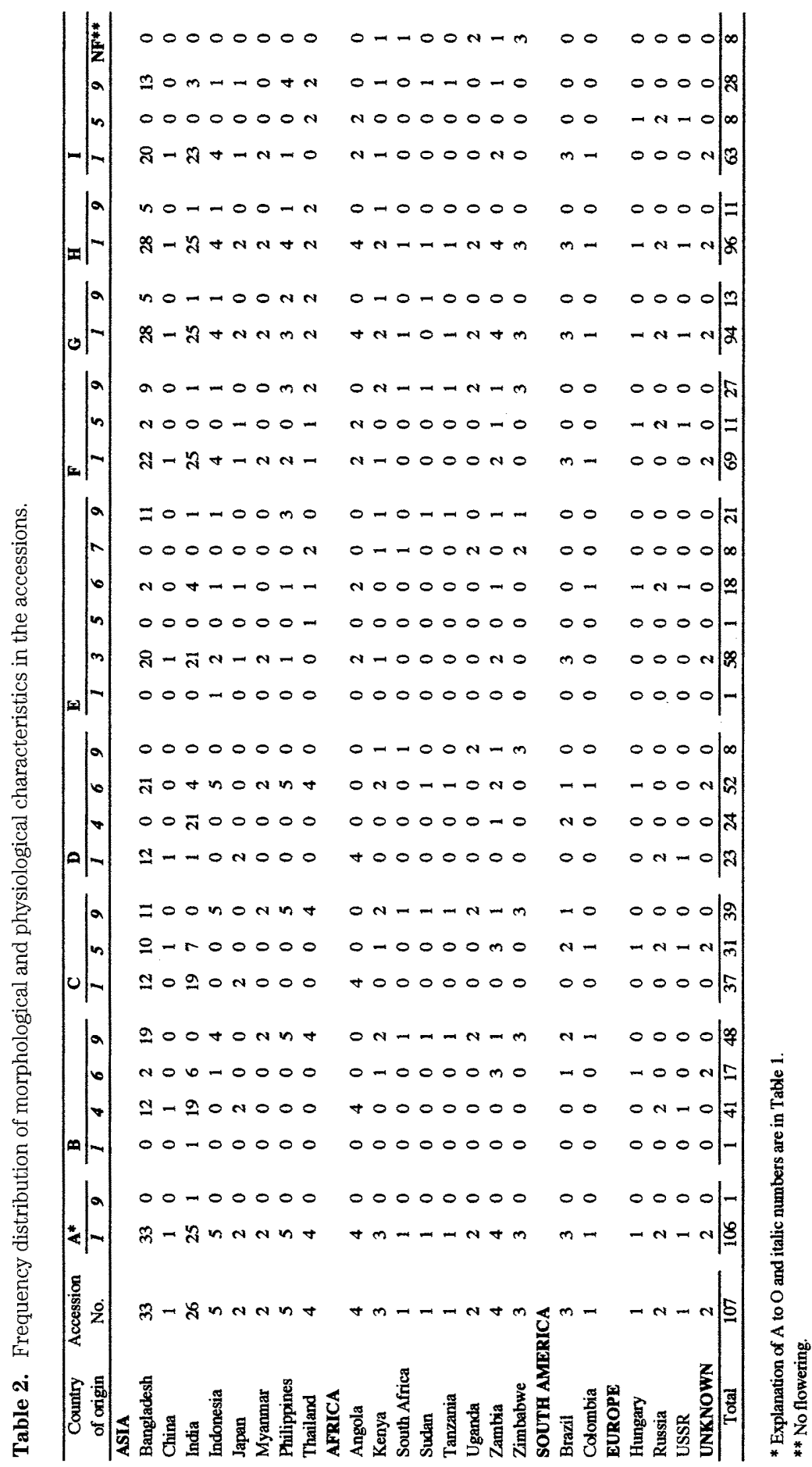




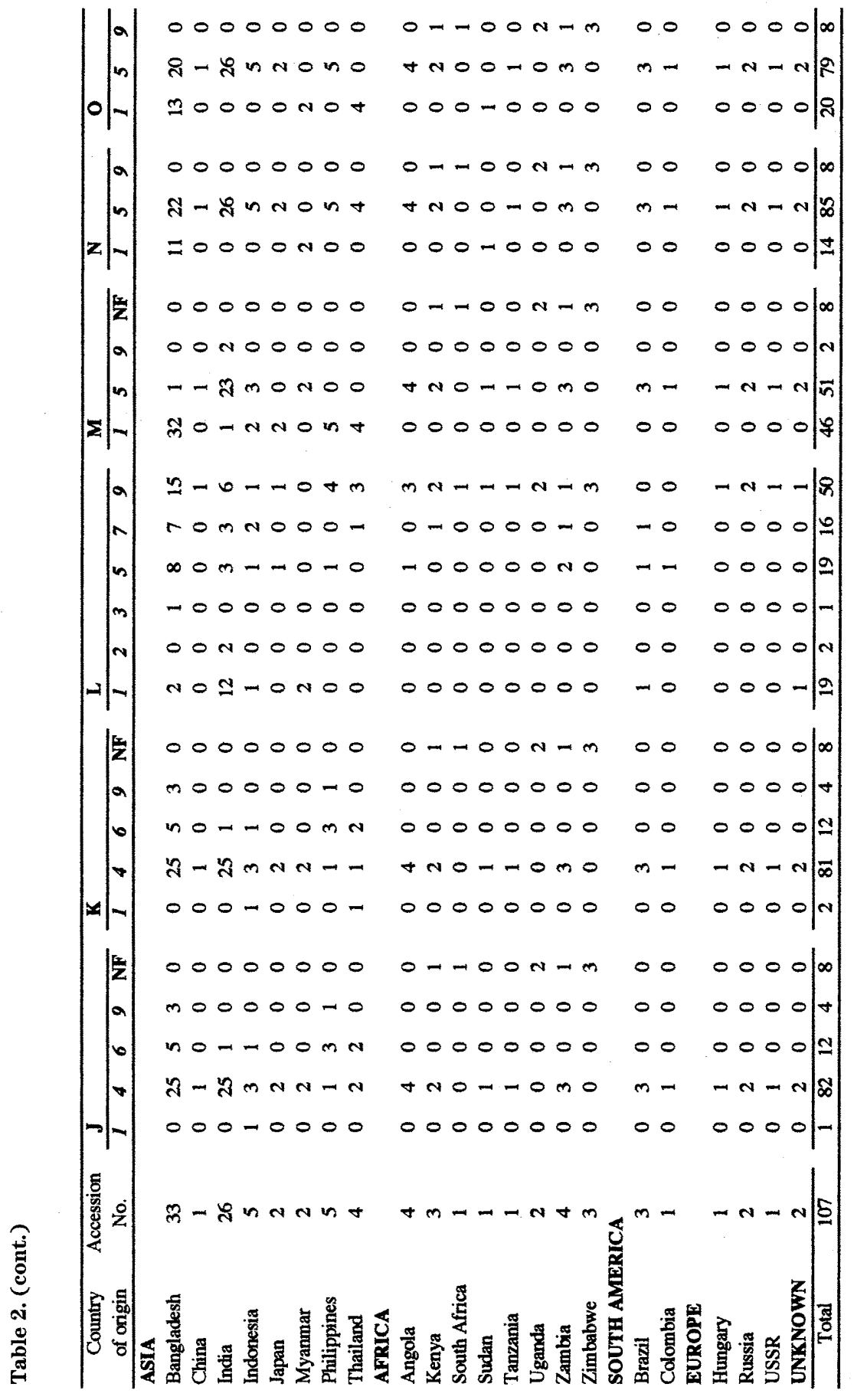


Number of SS and LS type accessions in Asian collections was equal (34 and 34). Most of the Asian SS types were from Indian and Bangladeshi accessions along with two Japanese accessions. All Bangladeshi SS type was developed at IPSA and they were all photoinsensitive. All other Asian accessions along with Bangladeshi local land races were LS type and photosensitive except one Chinese accession which was MS type and photoinsensitive. Photosensitivity appears to have relations to plant type; dwarf bush and small spreading vine (SS) types are insensitive to less sensitive, whereas large spreading (LS) type plants are sensitive to highly sensitive to photoperiod.

Among 19 African collections, 79\% were MS to LS types and $74 \%$ were sensitive to highly sensitive types. Eight of 11 African accessions with LS type were extremely spreading type and they were highly photosensitive. They were all represented from wild types and possessed some unique morphological characteristics, for example, such as very small leaf and seed size.

\section{Pigmentation on stem, petiole, leaf vein and margin, petal, sepal, pod and seed coat}

No direct association of stem and seed coat colors were observed. All the six types of stem colors (light green to purple) and seed coat colors (yellowish white to black) were found in Asia, whereas four types of stem colors and three types of seed coat colors were in Africa. Green was the dominating stem color in Asia, whereas various colors were in Africa.

A dominating petiole color in Asian accessions was green, whereas in Africa, purple was the major color. For petal colors in African accessions, although $42 \%$ could not be judged as they did not flower, $26 \%$ was white, $11 \%$ was light purple and $21 \%$ was purple, whereas Asian accessions had white petals with high percentage (69\%). In most cases, accessions with purple stem color had purple petals, and those with green stem color had white petals. Most of the accessions with green stem showed green petiole color and those with purple stem had purple petiole. Seed color of 36 accessions out of $42(=86 \%)$ with purple or light purple petals was black, indicating an association of the colors of the two organs.

Colors of leaf margin and vein were green or purple only, but no regional gene pool was revealed. Only $12 \%$ accessions had purple leaf margin and $10 \%$ had purple vein colors. Accessions with purple stem and purple petiole not always had purple leaf margin. Only five accessions from Bangladesh and one from each of India, Indonesia and Philippines had purple stem, petiole, leaf margin, leaf vein, petals and pods.

Most of the accessions had green sepal and pod colors followed by mixed colors of green and purple, and then purple. All the variations of sepal and pod colors were observed in Asian accessions, whereas their colors were only green in African accessions that flowered. There seems to be a close association between sepal and pod colors. For example, in one accession of Thailand had white sepal with purple blotch on it and its pod color was white with purple margin. Similarly, one accession of Indonesia had white sepal color also had white pod color.

\section{Pod length and leaf and seed size}

Among 99 accessions number of long and medium pods were close (46 and 51), and only two accessions from India had small pods. No association of pod size to leaf size or 


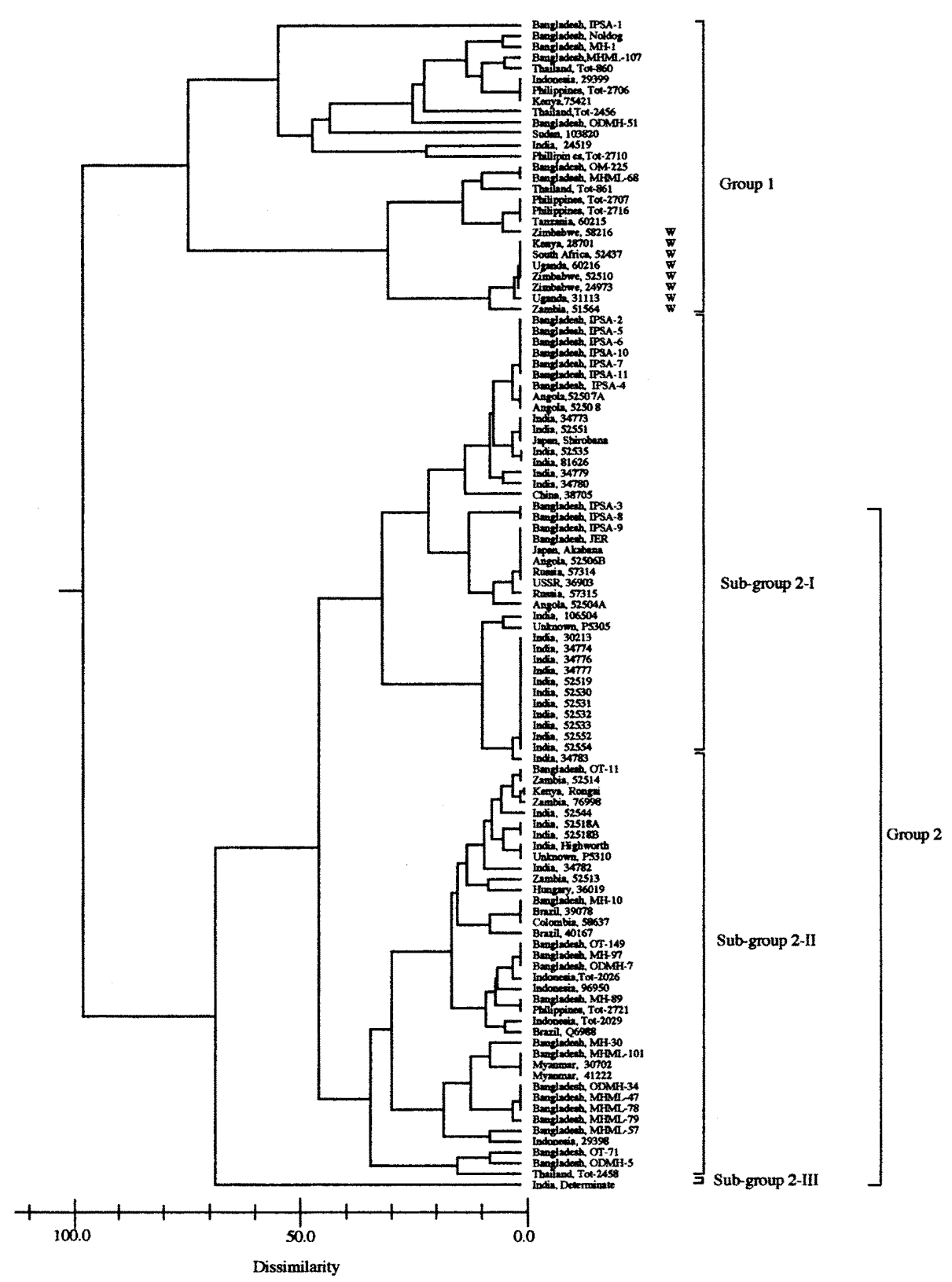

Fig. 1. Dendrogram of 107 accessions of lablab bean constructed by morphological and physiological characteristics using UPGMA based on Squared Euclidean dissimilarity values. Wild type accessions are marked as $W$. 
to seed size was revealed.

Ninety-nine accessions had big to medium leaves and also large to medium seeds. Only eight African accessions had small leaves and small seeds.

\section{Cluster analysis}

Cluster analysis grouped the accessions into two major groups, Group 1 and Group 2 (Fig. 1). All eight wild accession were classified into Group 1 together with the accessions from Kenya (one accession), Tanzania (1), Sudan (1) and some Asian accessions such as those from Bangladesh (7), Thailand (3), Indonesia (1), Philippines (4) and India (1). The characters that divided the accessions into two groups seemed to be plant type and colors of stem, petiole, leaf margin and leaf vein. Group 1 mainly consisted of the plants with large spreading vine (LS) except only one accession from Bangladesh (IPSA-1), whereas Group 2 involved dwarf bush, small to medium spreading vine (SS and MS). Stem, petiole, leaf margin or leaf vein color was purple in all the accessions in Group 1, but the color of these organs/parts was not purple in those classified into Group 2, except IPSA-3, IPSA-8, ODMH-5 and OT-71 from Bangladesh.

Group 2 was clustered into three sub-groups. Sub-group 2-I was dominated by Indian accessions (18 of 26 Indian accessions). All accessions from Angola, Russia, USSR, Japan and China were also in this sub-group. Most of the accessions of this sub-group were SS type and had a few branches. Sub-group 2-II consisted of accessions from all four regions (Asia, Africa, South America and Europe) and they were all photosensitive. Sub-group 2-III was formed only with one determinate accession that was dwarf bush and photoinsensitive.

In spite of the existence of wild type accessions in Africa, collections from Asian region possessed much variability (dissimilarity value ranged from $0.0-80.5$ ). It was difficult to consider the place of origin of this plant from the present study.

\section{REFERENCES}

Konduri, V., I. D. Godwin and C. J. Liu 2000 Genetic mapping of Lablab purpureus genome suggests the presence of 'cuckoo' gene (s) in this species. Theor. Appl. Genet., 100: 866-871

Lloyd, D. L., K. P. Smith, N. M. Clarkson, E. J. Weston and B. Johnson 1991 Sustaining multiple production system. 3. Lay pastures in the subtropics. Trop. Grassl., 25: 181-188

Piper, C. V. and W. J. Morse 1915 The bonavist, lablab or hyacinth bean. U. S. D. A. Bull. No. 138, pp. $1-15$

Purseglove, J. W. 1977 Tropical Crops. Dicotyledons. Longman, London, pp. 273-276

Rashid, M. M. 1993 Shabji Biggan, Bangla Academy, Dhaka, Bangladesh (In Bengali)

Shivashankar, G., Chikkadevaih and S. R. Hiremath 1977 Germplasms of field bean. Indian J. Genet. Plant Breed., 37: 353-371

Shivashankar, G., R. S. Kulkarni, H. E. Shashidhar and D. M. Mahishi 1993 Improvement of field bean. In "Advances in Horticulture Vol. 5. Vegetable Crops" ed. by K. L. Chadha and G. Kallo, New Delhi, pp. $277-286$ 